\title{
Evaluating the Performance of AquaCrop Model in Simulating the Productivity of Potato (Solanum tuberosum L.) Crop under Various Water Levels at Debre Birhan, Amhara Regional State, Ethiopia
}

\author{
Tsegaye Getachew Mengistu ${ }^{1}$, Tewodros Assefa Nigussie $^{2}$, Ashebir Haile ${ }^{3, *}$, Awel Seid ${ }^{2}$ \\ ${ }^{1}$ Debre Birhan Agricultural Research Center, Debre Birhan, Ethiopia. \\ ${ }^{2}$ Department of Water Resources and Irrigation Engineering, Hawassa University Institute of Technology, Hawassa, Sidama, \\ Ethiopia. \\ ${ }^{3}$ Ethiopian Institute of Agricultural Research, Addis Ababa, Ethiopia.
}

\begin{abstract}
How to cite this paper: Tsegaye Getachew Mengistu, Tewodros Assefa Nigussie, Ashebir Haile, Awel Seid. (2021) Evaluating the Performance of AquaCrop Model in Simulating the Productivity of Potato (Solanum tuberosum L.) Crop under Various Water Levels at Debre Birhan, Amhara Regional State, Ethiopia. International Journal of Food Science and Agriculture, 5(4), 674-687.

DOI: 10.26855/ijfsa.2021.12.015
\end{abstract}

Received: October 15, 2021

Accepted: November 8, 2021

Published: November 19, 2021

*Corresponding author: Ashebir Haile, Ethiopian Institute of Agricultural Research, Addis Ababa, Ethiopia. Email: ashu_haile@yahoo.com

\begin{abstract}
In the future, the agricultural sector in many parts of the world is to produce more with less water. In this regard, this experimental study was carried out to evaluate the performance of AquaCrop model in simulating potato crop growth parameters under various water levels at Debre Birhan, Ethiopia (2019-2020). The simulated crop yield parameters were compared to experimental results for this purpose. The experiment was arranged in Randomized Complete Block Design, with four replications and under five water levels (115\%, 100\%, 85\%, 70\% and $55 \%$ ). The $100 \%$ water level was determined to be $377.2 \mathrm{~mm}$ of water depth in the growing season. The growth parameter and tuber yield were significant differences among the water levels at $\mathrm{p}<0.05$. The fresh potato tuber yield and water productivity ranges from 36.09 ton/ha to 43.13 ton/ha and $12.67 \mathrm{~kg} / \mathrm{m}^{3}$ to $10.5 \mathrm{~kg} / \mathrm{m}^{3}$ were obtained in 55\% and 115\% water levels respectively. The AquaCrop model performance in the canopy cover, dry aboveground and tuber biomass and soil water content of the potato crop. The statistical indicators; Nash-Sutcliffe efficiency (NSE), Normalized Root mean square error (NRMSE) index of agreement (d) and Coefficient of determination $\left(\mathrm{R}^{2}\right)$ showed very well to excellent efficiency, there value is in ranges on aboveground and tuber biomass ranges 0.78 to $0.99,14.1$ to 35.5, 0.96 to 0.99 and 0.96 to 0.98 was observed respectively. However, the results of soil water content before irrigation were found to be poor efficiency ranges -0.96 to $0.00,10.2$ to $10.7,0.5$ to 0.780 .081 to 0.45 respectively in the above order. From the results of the study, we can conclude in two scenarios: First, in case of water scarce area, it may be more profitable for a farmer to maximize crop water productivity instead of maximizing the harvest per unit of land. The saved water can be used to irrigate extra units of land. Second, in case of no water scarce area, it may be more profitable to maximize the yield harvest than crop water productivity. Under the first scenario, farmers should adopt $70 \%$ of crop water requirement with a 10 -days interval, which $16.65 \%$ saved water with $10.1 \%$ yield penalty over $100 \%$. On the other hand, they should adopt $100 \%$ of crop water requirement within 10-days interval in the case of no water scarce area.
\end{abstract}

\section{Keywords}

AquaCrop, Water Scarcity, Water Levels, Water Productivity, Potato 


\section{Introduction}

Ethiopia is said to be rich in land and water resources, with a total land area of about 1.13 million $\mathrm{km}^{2}$ and annual surface water flow of 124 BMC. Despite this, however, the country is also known as one of the poorest countries in the world. Most of the problems in Ethiopia such as low agricultural productivity, low economic development, food insecurity and poverty are related to under and/or miss-utilization of water resources [1], stated that the economy of Ethiopia, which is heavily dependent on rain-fed subsistent agriculture, is extremely affected as a result of the erratic nature of the rainfall, frequent drought occurrence and little development of the available water resources. In Amhara Region of Ethiopia (the second most populous Region in the Country), the variability of the precipitation is manifested with an extended dry spell, erratic and highly variable in space and time [2]. The problem of food security has been intensifying as a result of rapid population growth and the consequent increase in demand for food and Region is one of the regions in Ethiopia suffering from food shortage every year [3].

Provided it is economically viable, irrigation could become a key source of agricultural growth as well as poverty relief for farmers, who otherwise would unjustifiably depend on low and erratic rainfall. This would help increase the productivity of the land, although to a limited extent, the need for extending the cultivated area for feeding the rapidly growing population [4]. Irrigation development is viewed as one of the strategies as means to reduce poverty and promote economic growth by the Ethiopian Government [5]. As stated by [6], irrigation development has been viewed as one of the main strategies to free the economy from rain fed-based agriculture and enable sustainable growth and development in Ethiopia through enhancing public and private investment. This is because irrigation increases productivity and production, reduces risk of crop failure due to drought, enables farmers to diversify the crops they grow, and produce high-value market-oriented crops and employs farmers in various income generating schemes [1].

Nonetheless, the traditional irrigation is an old age practice in Ethiopia, the irrigation practice under such schemes is considered as poor as these schemes consist of elementary structures like diversion weirs that are made of local material which tend to be washed away by floods nearly every year and unlined canals. Moreover, particularly in Amhara Region, there exists poor management of the existing limited amount of water resources, and there is a limitation of knowledge about how much and when to irrigate various crops. Therefore, there is a need to improve the water use efficiency to obtain more crop production per drop of water with declining irrigation resources and the uncertainty in the temporal and spatial distribution of rainfall. Among many, one of the mechanisms or strategies to improve crop productivity per unit of water under rain-fed, full irrigation and deficit irrigation is the employment of the aid of models to fill the gaps during dry spells [7]. In addition, knowing the response of crops to soil moisture stress is crucial for irrigation water management [8].

The solution to the above-mentioned issues and improve productivity at the farm level is better irrigation water management. This can be accomplished by determining water productivity under different irrigation regimes or deficit irrigation approach [9], based on experimental results or by using appropriate prediction tools. However, determining irrigation scheduling merely based on field research is expensive and time-consuming and, thus, the application of models in such studies is crucial. Some physical-based models developed for such purpose include the Crop System model (CropSyst) [10], the Decision Support System of Agro-Technology Transfer (DSSAT) [11], the World Food Studies crop growth model (WOFOST) [12] and the AquaCrop model.

Among the above-mentioned models, AquaCrop is known to provide a valid alternative for herbaceous crops, as incorporation of advanced knowledge of crop-water relationships allowing a more accurate modeling of actual crop growth and yield formation processes under various soil water availability, climate and soil fertility conditions [13]. It is water-driven model used as decision support tool in planning and scenario analysis in different seasons and location at farm level. It also elaborates the fundamental process involved in crop productivity and the response to water deficits [14]. It is widely applicable due to the only use the relatively small number of explicit parameters and mostly-intuitive input-variables that can be determined by simple methods. Besides, the calculation procedures are based on the basic biophysical processes to guarantee an accurate simulation of the crop response in the plant-soil system [15, 16].

Potato (Solanum tuberosum L.) is selected in this study as it is by far the most important tuber crop in terms of quantities produced and consumed worldwide [17]. This crop is considered as a high-potential food security crop due to its ability to provide high yield and quality product per unit input [18]. It is also because Ethiopia has possibly the greatest potential for potato production as $70 \%$ of its arable land mainly in the highlands with an altitude greater than 1,500 m above sea level is considered suitable for potato [19]. The objective of the study was, therefore, to evaluate the performance of AquaCrop model in simulating potato crop growth parameters under various water levels at Debre Birhan, Amhara Region, Ethiopia as such a study has not been carried out in the study area. 


\section{Materials and methods}

\subsection{Description of the study area}

This study was conducted at Debre Birhan Agricultural Research Centre (DBARC) experimental site located in North Shewa Administrative Zone, Amhara National Regional State, Ethiopia (Figure 1). The location is $09^{\circ} 36^{\prime} 30.5^{\prime \prime}$ North, $39^{\circ} 30^{\prime} 29.8^{\prime \prime}$ 'East and it has a mean elevation of 2,815 m above mean sea level. It is at about $121 \mathrm{~km}$ north of Addis Ababa and $9 \mathrm{~km}$ far from Debre Birhan Town in the South direction.

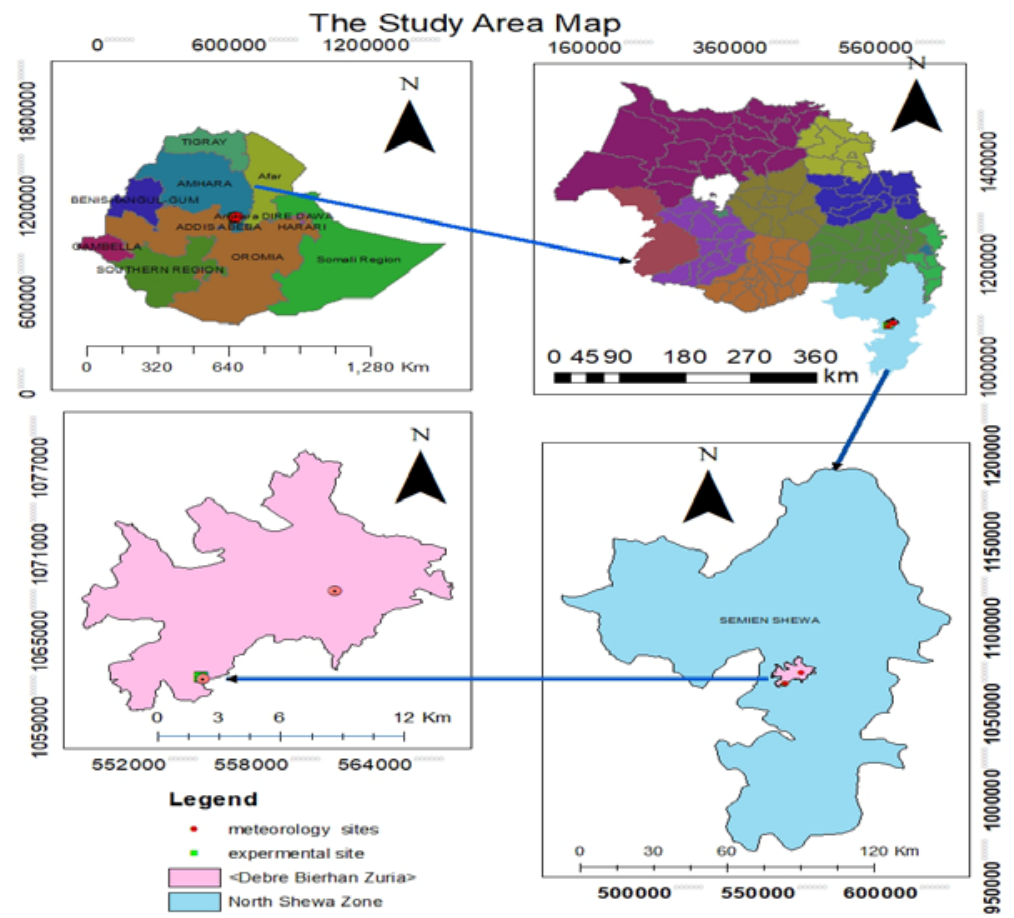

Figure 1. Location of the experimental site.

\subsection{Acuacrop Model Description}

AquaCrop is a crop water productivity model developed by the Land and Water Division of FAO. It simulates yield response to water of herbaceous crops, and is particularly suited to address conditions where water is a key limiting factor in crop production. It is designed to balance simplicity, accuracy and robustness, and is particularly suited to address conditions where water is a key limiting factor in crop production. AquaCrop is a companion tool for a wide range of users and applications including yield prediction under climate change scenarios.

As in other models, AquaCrop model structures its soil-crop-atmosphere continuum by including: (1) the soil, with its water balance; (2) the plant, with its growth, development, and yield processes; and (3) the atmosphere, with its thermal regime, rainfall, evaporative demand, and carbon dioxide concentration. Additionally, some management aspects are explicit, with emphasis on irrigation, but also the levels of soil fertility as they affect crop development, water productivity, and crop adjustments to stresses, and therefore final yield.

\subsection{Performance evaluation of AquaCrop model}

Model performance evaluation is an important step of model verification and involves a comparison between independent field measurements (data) and output created by the model. Soil water content over the root depth, above-ground dry biomass and tuber yield were considered in this study for model evaluation (Table 1).

\subsection{Experimental design}

Field experiment is an important task to validate the model result with the observed data in order to obtain accurate prediction versus observed data. In this regard, the experiment was arranged in Randomized Complete Block Design (RCBD) within five irrigation treatments. The plot size was $3 \mathrm{~m} \times 3.75 \mathrm{~m}=11.25 \mathrm{~m}^{2}$ area and total experimental area $19.5 \mathrm{~m} * 19 \mathrm{~m}=370.5 \mathrm{~m}^{2}$. And $1 \mathrm{~m}$ and $1.5 \mathrm{~m}$ apart between plots and blocks respectively was as shown in Figure 2 . 


\subsection{Data input parameters}

On basic and complex biophysical processes, AquaCrop uses a relatively small number of explicit parameters and largely-intuitive input variables, either widely used or requiring simple methods for their determination. The inputs are stored in climate, crop, soil and management files and can be easily changed through the user-interface.

Table 1. Statistical performance indictors

\begin{tabular}{|c|c|c|c|}
\hline No & Statistical indictors & Formulas & Agreements \\
\hline 1 & Coefficient of determination $\left(\mathrm{R}^{2}\right)$ & $R^{2}=\left[\frac{\sum\left(O_{i}-\overline{O_{i}}\right)\left(P_{i}-\overline{P_{i}}\right)}{\sqrt{\sum\left(O_{i}-\overline{O_{i}}\right)^{2}\left(P_{i}-\overline{P_{i}}\right)^{2}}}\right]^{2}$ & $\begin{array}{l}0 \text { to } 1 \text {, with values close to } 1 \text { indicating a good } \\
\text { agreement }\end{array}$ \\
\hline 2 & Root Mean Square Error (RMSE) & $R M S E=\frac{\sqrt{\sum\left(p_{i}-O_{i}\right)^{2}}}{N}$ & $\begin{array}{l}\text { It ranges from } 0 \text { to } 1 \text { the value } 0 \text { indicating good and } \\
\text { the value } 1 \text { indicating poor model performance. }\end{array}$ \\
\hline 3 & $\begin{array}{l}\text { Normalized Root Mean Square } \\
\text { Error (NRMSE) }\end{array}$ & $N R M S E=\frac{1}{\bar{Q}_{i}} X \frac{\sqrt{\sum\left(p_{i}-O_{i}\right)^{2}}}{N} \otimes 100$ & $\begin{array}{l}\text { A model can be considered excellent if NRMSE is } \\
<10 \% \text {, good if between } 10 \text { and } 20 \% \text {, fair if between } \\
20 \text { and } 30 \% \text { and poor if }>30\end{array}$ \\
\hline 4 & Nash-Sutcliffe Efficiency (NSE) & $N S E=1-\frac{\sum(O i-P i)^{2}}{\sum(O i-\overline{O i})^{2}}$ & $\begin{array}{l}\text { data are that to fits the } 1: 1 \text { line indicates a perfect } \\
\text { match between the model and the observations. }\end{array}$ \\
\hline 5 & Willmott’s index of agreement (d) & $d=1-\frac{\sum(P i-O i)^{2}}{\sum(/ P i-\overline{O i} /+/ O i-\overline{O i})^{2}}$ & $\begin{array}{l}\text { It ranges between } 0 \text { and } 1 \text {, with } 0 \text { indicating no } \\
\text { agreement and } 1 \text { indicating a perfect agreement } \\
\text { between the predicted and observed data: }\end{array}$ \\
\hline
\end{tabular}

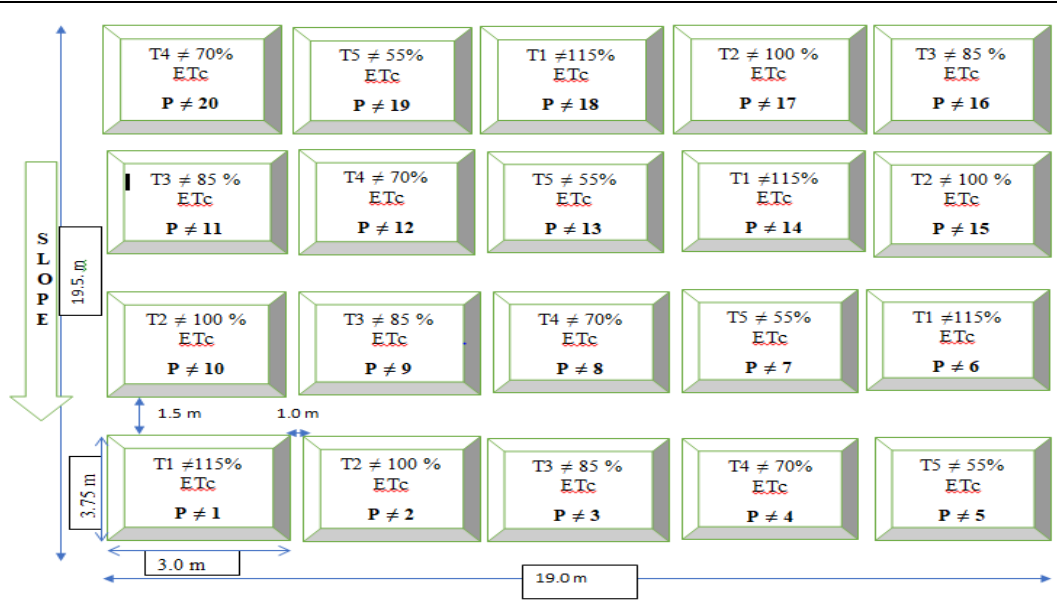

Figure 2. Experimental lay out.

\subsubsection{Climate file}

Historical climate data such as rainfall, minimum and maximum temperature, relative humidity, wind run at 2 meter and sunshine hour duration of 40 year (1979-2018) obtained from two principal stations that $9 \mathrm{~km}$ far apart to each other (located at DBARC and Debre Birhan Town) were used for simulating the test crop growth parameters using the AquaCrop model. For the $\mathrm{CO}_{2}$ file was determined automatically adjusted by AquaCrop software by using the reference of the 2000-year $369.55 \mathrm{ppm}$ and increment about $2 \mathrm{ppm}\left(\mathrm{y}=1.8034 \mathrm{x}-3234.9\right.$ with $\left.\mathrm{R}^{2}=0.9905\right)$ every year. This $\mathrm{CO}_{2}$ concentration data from international rice research institute (IRRI) the model was IPCC: RCP 8.5. After inputted the above climatic data and the geo-referenced data then the model created an ETo, rain, temperature and $\mathrm{CO}_{2}$ file.

\subsubsection{Created crop file}

For created crop file first marked the file name and described the crop type that was potato crop under root and tuber crop, and then specified parameters. The AquaCrop generated the complete set of required crop parameters from the agronomic perspective of the crop nature in that specific location. As presented in Appendix Table 1, Appendix Table 2, the parameters were displayed and the values of non-conservative parameters and generated the model for conservative parameters respectively. 


\subsubsection{Created soil file}

In creating a soil file, the user has to specify only a few characteristics like soil type, depth of soil, texture, etc. With the assistance of this information, AquaCrop generated the complete set of soil parameters. The parameters were displayed and the values adjusted or modified in the soil profile characteristics menu. The soil physical characteristics such as field capacity, permanent wilting point bulk density and a textural class of the experimental sites was presented as follows.

\subsubsection{Created management file (irrigation schedule)}

For created an irrigation schedule, the user specifies the time and application depth of the irrigation events. The volume of water applied for $100 \%$ ETc irrigation treatments were determined after several simulation of the AquaCrop model run by running several times (by trial and error) during simulating time, then accordingly for other water level treatments was determined as per their percentages.

The Values of crop coefficients (Ks) were used from FAO, Irrigation and Drainage Paper no 24 paper [20]. The coefficient of each irrigation treatment was Ks $(1)=100 \%$ of ETc no stress, Ks $(0.85)=85 \%$ of ETc, Ks $(0.70)=70 \%$ of Etc, Ks $(0.55)=55 \%$ of ETc, and Ks $(1.15)=115 \%$ of ETc. The irrigation water was applied for all treatments on the same day as that of fully irrigated plot (T2). while the irrigation depths were varied as their percentage $115 \%, 85 \%$, $70 \%$, and $55 \%$, of the full irrigation for $T_{1}, T_{3}, T_{4}, T_{5}$ treatments respectively.

The seasonal amount of irrigation water from each treatment was recorded. In full irrigation, treatment (100\%) the AquaCrop model was adjusted at 35\% root zone depletion and refill to the field capacity. Before starting, the treatment there was applied equally for all treatment every 5-day interval. The irrigation method was used with a garden hose from water tanker on the average the rate of $0.20833 \mathrm{lit} / \mathrm{sec}$. During rainfall, the irrigation water was applied after calculating the effective rainfall using the AquaCrop model.

\subsection{Statistical analyses}

The results were subjected to the analysis of variance (ANOVA) procedure, using SAS 9.0 statistical software to investigate whether there are statistical differences in the parameter studied (canopy cover, water content, and water productivity, and yield and yield components) or not. The mean comparisons were done using LSD test due to small number of treatments involved and comparison was done between the control treatment $(100 \%)$ of water level at a probability level of $\mathrm{p}<0.05$ for separation of means [21].

\section{Results and discussion}

\subsection{Performance of AquaCrop on dry-aboveground and tuber biomass yield in year 2019\& 2020 G.C.}

As presented in Table 2 and Table 3, the dry aboveground and tuber biomass yield had excellent in the Nash-Sutcliffe Efficiency (NSE) (0.96, 0.94, 0.90, 0.84 \& 0.78 in year 2019 G.C. and 93, 93, 90, 95 \& 98 in year 2020 G.C.) was obtained for the water levels $115 \%, 100 \%, 85 \%, 70 \%$ and 55\%, respectively. For normalized root mean square error (NRMSE) had fair to poor values $(14.1 \%, 16.3 \%, 21.6 \%, 28.1 \%$ \& $35.5 \%$ in year 2019 G.C and $17.1 \%, 17.8 \%, 21.30 \%$, $15.50 \% \& 10.0 \%$ in year 2020 G.C.) was observed for the water levels $115 \%, 100 \%, 855,70 \%$ and $55 \%$, respectively. As well for index of agreement (d) had excellent value $(0.99,0.99,0.98,0.97 \& 0.96)$ for the water levels $115 \%, 100 \%$, $85 \%, 70 \%$ and $55 \%$ respectively. The simulated result on coefficient of determination $\left(\mathrm{R}^{2}\right)$ had excellent value $(0.96$, 0.96, 0.96, 0.98 and 0.98 in year 2019 G.C. and 98, 98, 98, 99 \& 99 in year 2020 G.C.) for the water levels $115 \%, 1,005$, $85 \%, 70 \%$ and $55 \%$ respectively. The results show that the well to excellent correlated as simulated value. The results in line with the study of the AquaCrop model performance in Tigray on potato were found a satisfactory result on the NRMSE [22].

\subsection{Performance of AquaCrop on simulating canopy cover in year 2019 \& 2020 G.C.}

As presented in Table 4 and Table 5, the canopy covers as indicated by excellent to good model efficiency NSE (0.96, 0.82, 0.76, 0.0 .68 \& 0.54 in year 2019 and 94, 93, 85, 78 \& 73 in year 2020 G.C.) for the water levels $115 \%, 100 \%$, 85\%, 70\% and 55\%, respectively. For normalized root mean square error NRMSE very good to good (fair) (12.9\%, 15\%, 18.7\%, 20.5\% and 25\% in year 2019 and 10.1, 11.2, 16.9, 20.4 \& 23.0 in year 2020 G.C.) for the water levels $115 \%, 100 \%, 85 \%, 70 \%$ and $55 \%$ of water level, respectively. As well for the index of agreement (d) was excellent (0.97, 0.96, 0.95, 0.93 and 0.91 in year 2019 and 99, 98, 97, 95 \& 94 in year 2020 G.C.) for the water levels 115\%, $100 \%, 85 \%, 70 \%$ and $55 \%$, respectively. The simulated result on the coefficient of determination $\mathrm{R}^{2}$ was excellent $(0.96$, 0.94, 0.94, 0.94 and 0.92 in year 2019 and 98, 98, 96, 96 \& 94 in year 2020 G.C.) for the water levels $115 \%, 100 \%$, $85 \%, 70 \%$ and 55\%, respectively. The results showed that the AquaCrop model very well simulated value observed on in all water levels. This result agreed with [22], in Tigray, Ethiopia. Another result shows index of agreement (d) and coefficient of determination $\left(\mathrm{R}^{2}\right)$ was found $>90 \%$ in Spain [23]. 
Table 2. Observed and simulated dry aboveground biomass and dry tuber weight 2019 G.C.

\begin{tabular}{|c|c|c|c|c|c|c|c|c|c|c|}
\hline DaP & $\begin{array}{c}115 \% \\
\text { DAGB t/ha } \\
\text { OBS }\end{array}$ & $\begin{array}{c}115 \% \\
\text { DAGB } \\
\text { t/ha SIM }\end{array}$ & $\begin{array}{c}100 \% \\
\text { DAGB t/ha } \\
\text { OBS }\end{array}$ & $\begin{array}{c}100 \% \\
\text { DAGB } \\
\text { t/ha SIM }\end{array}$ & $\begin{array}{c}\text { 85\% DAGB } \\
\text { t/ha OBS }\end{array}$ & $\begin{array}{c}85 \% \\
\text { DAGB } \\
\text { t/ha SIM }\end{array}$ & $\begin{array}{c}70 \% \\
\text { DAGB } \\
\text { t/ha OBS }\end{array}$ & $\begin{array}{c}70 \% \\
\text { DAGB } \\
\text { t/ha SIM }\end{array}$ & $\begin{array}{c}55 \% \\
\text { DAGB } \\
\text { t/ha OBS }\end{array}$ & $\begin{array}{c}55 \% \\
\text { DAGB t/ha } \\
\text { SIM }\end{array}$ \\
\hline 34 & 0.083 & 0.092 & 0.077 & 0.092 & 0.073 & 0.092 & 0.065 & 0.092 & 0.054 & 0.092 \\
\hline 44 & 0.693 & 0.941 & 0.628 & 0.941 & 0.586 & 0.941 & 0.535 & 0.941 & 0.517 & 0.941 \\
\hline 54 & 2.486 & 2.891 & 2.326 & 2.891 & 2.138 & 2.891 & 2.045 & 2.89 & 1.906 & 2.89 \\
\hline 64 & 5.36 & 4.965 & 4.618 & 4.965 & 4.121 & 4.965 & 3.663 & 4.964 & 3.277 & 4.963 \\
\hline 74 & 8.326 & 7.028 & 7.781 & 7.028 & 7.059 & 7.028 & 6.175 & 7.027 & 5.925 & 7.027 \\
\hline 86 & 10.265 & 9.471 & 9.641 & 9.47 & 8.711 & 9.47 & 8.326 & 9.469 & 7.764 & 9.467 \\
\hline 95 & 11.717 & 11.265 & 11.495 & 11.264 & 11.474 & 11.264 & 10.409 & 11.263 & 9.762 & 11.082 \\
\hline 106 & 12.401 & 13.372 & 11.856 & 13.372 & 11.491 & 13.372 & 10.553 & 13.267 & 10.044 & 12.72 \\
\hline 117 & 12.742 & 15.015 & 12.301 & 15.015 & 11.6255 & 15.015 & 11.169 & 14.628 & 10.032 & 13.671 \\
\hline $\mathbf{R}$ & $0.98^{* * * *}$ & & $0.98^{* * *}$ & & $0.98^{* * * *}$ & & $0.99^{* * * *}$ & & $99^{* * * *}$ & \\
\hline RMSE & $1.00^{*}$ & & $1.10^{*}$ & & $1.40^{*}$ & & $1.70^{+}$ & & $1.8^{+}$ & \\
\hline NRMSE & $14.10^{* *}$ & & $16.30^{*}$ & & $21.60^{*}$ & & $28.10^{+}$ & & $33.5^{+}$ & \\
\hline NSE & $0.96^{* * * *}$ & & $0.94^{* * *}$ & & $0.90^{* * * *}$ & & $0.84^{* * * *}$ & & $0.78^{* * *}$ & \\
\hline $\mathbf{R}^{2}$ & $0.96^{* * *}$ & & $0.96^{* * *}$ & & $0.96^{* * *}$ & & $0.98^{* * * *}$ & & $0.98^{* * * *}$ & \\
\hline
\end{tabular}

Notes. (Field experiment, 2019) DaP is day after planting DAGB is dry aboveground biomass OBS is observed, SIM is simulated ${ }^{*}$ good, ${ }^{* *}$ very well, **** excellent, and + poor.

Table 3. Observed and simulated dry aboveground biomass and dry tuber weight 2020 G.C.

\begin{tabular}{|c|c|c|c|c|c|c|c|c|c|c|}
\hline DaP & $\begin{array}{c}115 \% \\
\text { DAGB } \\
\text { t/ha OBS }\end{array}$ & $\begin{array}{c}115 \% \\
\text { DAGB } \\
\text { t/ha SIM }\end{array}$ & $\begin{array}{c}100 \% \\
\text { DAGB t/ha } \\
\text { OBS }\end{array}$ & $\begin{array}{c}100 \% \\
\text { DAGB } \\
\text { t/ha SIM }\end{array}$ & $\begin{array}{c}\text { 85\% DAGB } \\
\text { t/ha OBS }\end{array}$ & $\begin{array}{c}85 \% \\
\text { DAGB } \\
\text { t/ha SIM }\end{array}$ & $\begin{array}{c}70 \% \\
\text { DAGB } \\
\text { t/ha OBS }\end{array}$ & $\begin{array}{c}70 \% \\
\text { DAGB } \\
\text { t/ha SIM }\end{array}$ & $\begin{array}{c}55 \% \\
\text { DAGB } \\
\text { t/ha OBS }\end{array}$ & $\begin{array}{c}\text { 55\% DAGB } \\
\text { t/ha SIM }\end{array}$ \\
\hline 31 & 0.076 & 0.063 & 0.074 & 0.063 & 0.064 & 0.063 & 0.065 & 0.063 & 0.051 & 0.063 \\
\hline 41 & 0.664 & 0.365 & 0.582 & 0.365 & 0.589 & 0.365 & 0.569 & 0.362 & 0.547 & 0.354 \\
\hline 52 & 2.496 & 1.647 & 2.288 & 1.646 & 2.136 & 1.646 & 2.056 & 1.615 & 1.871 & 1.523 \\
\hline 61 & 4.411 & 3.332 & 4.178 & 3.332 & 3.960 & 3.331 & 3.805 & 3.278 & 3.755 & 3.104 \\
\hline 71 & 6.126 & 5.334 & 5.795 & 5.334 & 5.114 & 5.332 & 4.871 & 5.263 & 4.683 & 4.942 \\
\hline 81 & 8.309 & 7.357 & 8.153 & 7.356 & 7.552 & 7.354 & 6.843 & 7.283 & 6.515 & 6.732 \\
\hline 91 & 10.429 & 9.361 & 10.223 & 9.361 & 9.176 & 9.359 & 9.008 & 9.206 & 8.184 & 8.221 \\
\hline 102 & 11.598 & 11.537 & 11.633 & 11.536 & 10.966 & 11.534 & 10.757 & 10.955 & 9.550 & 9.525 \\
\hline 112 & 12.156 & 13.465 & 12.017 & 13.465 & 11.278 & 13.364 & 10.864 & 12.254 & 9.792 & 10.483 \\
\hline 122 & 12.605 & 15.344 & 12.277 & 15.344 & 11.475 & 14.965 & 11.022 & 13.417 & 9.970 & 11.334 \\
\hline $\mathbf{R}$ & $0.98^{* * *}$ & & $0.98^{* * *}$ & & $0.99^{* * * *}$ & & $0.99^{* * * *}$ & & $0.99^{* * *}$ & \\
\hline RMSE & $1.2^{*}$ & & $1.2^{*}$ & & $1.3^{*}$ & & $0.9^{*}$ & & $0.6^{* *}$ & \\
\hline NRMSE & $17.1^{*}$ & & $17.8^{*}$ & & $21.3^{*}$ & & $15.5^{*}$ & & $10^{* *}$ & \\
\hline D & $0.99^{* * * *}$ & & $0.98^{* * *}$ & & $0.98^{* * * *}$ & & $0.99^{* * *}$ & & $0.98^{* * *}$ & \\
\hline $\mathbf{R}^{2}$ & $0.98^{* * * *}$ & & $0.98^{* * *}$ & & $0.99^{* * *}$ & & $0.99^{* * * *}$ & & $0.99^{* * *}$ & \\
\hline
\end{tabular}

Notes. (Field experiment, 2020) DaP is day after planting DAGB is dry aboveground biomass OBS is observed, SIM is simulated ${ }^{*}$ good, ${ }^{* *}$ very well, **** excellent, and + poor.

Table 4. Observed and simulated canopy cover (\%) 2019 G.C.

\begin{tabular}{|c|c|c|c|c|c|c|c|c|c|c|}
\hline DaP & $115 \%$ OBS & $115 \%$ SIM & $100 \%$ OBS & $100 \%$ SIM & $85 \%$ OBS & $85 \%$ SIM & $70 \%$ OBS & $70 \%$ SIM & $55 \%$ OBS & $55 \%$ SIM \\
\hline 34 & 7.125 & 5.8 & 6.8 & 5.8 & 6.3 & 5.8 & 5.792 & 5.8 & 5.667 & 5.8 \\
\hline 44 & 55.05 & 62.7 & 52.35 & 62.7 & 50.308 & 62.7 & 49.683 & 62.7 & 48.933 & 62.7 \\
\hline 54 & 84.842 & 89.6 & 85.008 & 89.6 & 83.158 & 89.5 & 81.475 & 89.5 & 77.375 & 89.4 \\
\hline 64 & 85.55 & 91.8 & 84.633 & 91.8 & 81.692 & 91.8 & 81.608 & 91.8 & 81.35 & 91.8 \\
\hline 74 & 88.892 & 92 & 88.375 & 92 & 85.267 & 92 & 84.108 & 92 & 82.967 & 92 \\
\hline 86 & 86.991 & 92 & 84.108 & 92 & 83.558 & 92 & 81.1 & 92 & 79.45 & 92 \\
\hline 96 & 85.208 & 90.9 & 84.975 & 90.9 & 81.967 & 90.9 & 81.267 & 90.9 & 74.658 & 90.9 \\
\hline 106 & 72.725 & 89.2 & 71.067 & 89.2 & 68.825 & 89.2 & 67.675 & 89.2 & 65.325 & 89.2 \\
\hline 115 & 70.833 & 87.2 & 68.067 & 87.2 & 64.883 & 87.2 & 61.983 & 87.2 & 57.508 & 87.2 \\
\hline $\mathbf{R}$ & $0.98^{* * *}$ & & $0.97^{* * *}$ & & $0.97^{* * * *}$ & & $0.97^{* * *}$ & & $0.96^{* * *}$ & \\
\hline RMSE & $9.1^{* *}$ & & $10.4^{*}$ & & $12.4^{*}$ & & $13.6^{*}$ & & $16^{*}$ & \\
\hline NRMSE & $12.9^{*}$ & & $15^{*}$ & & $18.7^{*}$ & & $20.5^{*}$ & & $25^{*}$ & \\
\hline NSE & $0.86^{* * *}$ & & $0.82^{* * * *}$ & & $0.76^{* * *}$ & & $0.68^{* *}$ & & 0.54 & \\
\hline D & $0.97^{* * *}$ & & $0.96^{* * *}$ & & $0.95^{* * *}$ & & $0.93^{* * *}$ & & $0.91^{* * *}$ & \\
\hline $\mathbf{R}^{2}$ & $0.96^{* * *}$ & & $0.94^{* * * *}$ & & $0.94^{* * *}$ & & $0.94^{* * * *}$ & & $0.92^{* * *}$ & \\
\hline
\end{tabular}

Notes. (Field experiment, 2020) DaP is day after planting, CC is canopy cover, OBS is observed, SIM is simulated, ${ }^{*}$ good, ${ }^{* *}$ very well, and ${ }^{* * *}$ excellent. 
Table 5. Observed and simulated canopy cover (\%) 2020 G.C.

\begin{tabular}{|c|c|c|c|c|c|c|c|c|c|c|}
\hline DaP & $115 \%$ OBS & $115 \%$ SIM & $100 \%$ OBS & $100 \%$ SIM & $85 \%$ OBS & $85 \%$ SIM & $70 \%$ OBS & $70 \%$ SIM & $55 \%$ OBS & $55 \%$ SIM \\
\hline 31 & 3.86 & 3.2 & 3.34 & 3.2 & 3.19 & 3.2 & 2.88 & 3.2 & 2.40 & 3.2 \\
\hline 41 & 24.39 & 16.2 & 22.58 & 16.2 & 17.87 & 16.2 & 16.72 & 16.2 & 14.29 & 15.4 \\
\hline 52 & 76.52 & 65 & 73.48 & 65 & 71.26 & 65 & 68.07 & 65 & 64.82 & 58.8 \\
\hline 61 & 85.48 & 82.6 & 83.81 & 82.6 & 80.10 & 82.6 & 77.69 & 82.6 & 74.52 & 76 \\
\hline 71 & 88.72 & 86.9 & 86.84 & 86.9 & 83.27 & 86.9 & 81.64 & 86.9 & 77.69 & 81.2 \\
\hline 81 & 85.93 & 87.7 & 83.28 & 87.7 & 80.81 & 87.7 & 80.22 & 87.7 & 76.67 & 84.2 \\
\hline 91 & 86.99 & 87.9 & 87.43 & 87.9 & 84.76 & 87.9 & 82.30 & 87.9 & 76.60 & 85.2 \\
\hline 102 & 79.87 & 87.6 & 78.14 & 87.6 & 71.09 & 87.6 & 67.91 & 87.6 & 65.07 & 84.9 \\
\hline 112 & 77.94 & 86.9 & 75.10 & 86.9 & 68.84 & 86.9 & 65.62 & 86.9 & 61.26 & 84.2 \\
\hline 122 & 75.12 & 86.1 & 72.27 & 86.1 & 66.02 & 86.1 & 62.79 & 86.1 & 58.43 & 83.4 \\
\hline $\mathbf{R}$ & \multicolumn{2}{|c|}{$0.98^{* * *}$} & \multicolumn{2}{|c|}{$0.98^{* * *}$} & \multicolumn{2}{|c|}{$0.96^{* * *}$} & \multicolumn{2}{|c|}{$0.96^{* * *}$} & \multicolumn{2}{|c|}{$0.94^{* * *}$} \\
\hline RMSE $t / h a$ & \multicolumn{2}{|c|}{$6.9^{* *}$} & \multicolumn{2}{|c|}{$7.4^{* *}$} & \multicolumn{2}{|c|}{$10.6^{*}$} & \multicolumn{2}{|c|}{$12.4^{*}$} & \multicolumn{2}{|c|}{$13.1^{*}$} \\
\hline (RMSE) \% & \multicolumn{2}{|c|}{$10.1^{* *}$} & \multicolumn{2}{|c|}{$11.2^{* *}$} & \multicolumn{2}{|c|}{$16.9^{*}$} & \multicolumn{2}{|c|}{$20.4^{*}$} & \multicolumn{2}{|c|}{$23^{*}$} \\
\hline NSE & \multicolumn{2}{|c|}{$0.94^{* * *}$} & \multicolumn{2}{|c|}{$0.93^{* * *}$} & \multicolumn{2}{|c|}{$0.85^{* * *}$} & \multicolumn{2}{|c|}{$0.78^{* *}$} & \multicolumn{2}{|c|}{$0.73^{* *}$} \\
\hline d & \multicolumn{2}{|c|}{$0.99^{* * *}$} & \multicolumn{2}{|c|}{$0.98^{* * *}$} & \multicolumn{2}{|c|}{$0.97^{* * *}$} & \multicolumn{2}{|c|}{$0.95^{* * *}$} & \multicolumn{2}{|c|}{$0.94^{* * *}$} \\
\hline
\end{tabular}

Notes. (Field experiment, 2020) DaP is day after planting, CC is canopy cover, OBS is observed, SIM is simulated, ${ }^{*}$ good, ${ }^{* *}$ very well, and ${ }^{* * *}$ excellent.

\subsection{Performance of AquaCrop in simulating soil water content after irrigation in year 2019 \& 2020 G.C.}

As presented in Table 6 and Table 7 and Figures 3-7, the soil water after irrigation had poor to excellent model efficiency NSE $(0.09,0.43,0.96,0.97$ and 0.98 in year 2019 and $0.48,0.73,0.89,0.93 \& 0.89$ in year 2020 G.C.) for the water levels $115 \%, 100 \%, 85 \%, 70 \%$ and $55 \%$ respectively. For normalized root mean square error, NRMSE excellent simulated as $(1.3 \%, 0.8 \%, 0.75,1.1 \%$ and $2.2 \%$ in year 2019 and $2.5,1.5,1.5,1.6, \& 2.5$ in year 2020 G.C.) for the water levels $115 \%, 100 \%, 85 \%, 70 \%$ and $55 \%$ respectively. As well for the index of agreement (d) was from very well to excellent values were observed $(0.86,0.85,0.99,0.99$ and 0.98 in year 2019 and $0.89,0.94,0.97,0.98 \& 0.98$ in year 2020 G.C.) for the water levels $115 \%, 100 \%, 85 \%, 70 \%$ and $55 \%$ respectively. The simulated result on the coefficient of determination $\mathrm{R}^{2}$ was very well to excellent simulated $(0.72,0.69,0.96,0.98$ and 0.96 in year 2019 and $0.88,0.91$, $0.99,0.98 \& 0.86$ in year 2020 G.C.) for the water levels $115 \%, 100 \%, 85 \%, 70 \%$ and $55 \%$ respectively. The results show that the well correlated as simulated values, however, the value of lower water levels better simulated than highest water level treatments. Generally, the soil water content after each irrigation for the simulation result was observed very well to excellent result validation results obtained.

Table 6. Observed and simulated SWC on Different water level after irrigation 2019 G.C.

\begin{tabular}{|c|c|c|c|c|c|c|c|c|c|c|}
\hline DaP & $\begin{array}{c}115 \% \text { AI } \\
\text { OBS }\end{array}$ & $\begin{array}{c}115 \% \text { AI } \\
\text { SIM }\end{array}$ & $\begin{array}{c}100 \% \text { AI } \\
\text { OBS }\end{array}$ & $\begin{array}{c}100 \% \mathrm{AI} \\
\text { SIM }\end{array}$ & $\begin{array}{c}855 \% A I \\
\text { OBS }\end{array}$ & $\begin{array}{c}85 \% \text { AI } \\
\text { SIM }\end{array}$ & $\begin{array}{c}70 \% \text { AI } \\
\text { OBS }\end{array}$ & $\begin{array}{c}70 \% \text { AI } \\
\text { SIM }\end{array}$ & $\begin{array}{c}55 \% \text { AI } \\
\text { OBS }\end{array}$ & $\begin{array}{c}55 \% \text { AI } \\
\text { SIM }\end{array}$ \\
\hline 2 & 372.2 & 376.4 & 373.8 & 376.4 & 374.4 & 376.4 & 371.2 & 376.4 & 372.2 & 376.4 \\
\hline 13 & 373.1 & 365.9 & 370.0 & 365.9 & 368.2 & 365.9 & 367.3 & 365.9 & 365.0 & 365.9 \\
\hline 20 & 369.5 & 364.7 & 367.2 & 364.7 & 369.4 & 364.7 & 372.4 & 364.7 & 369.0 & 364.7 \\
\hline 25 & 370.5 & 368.0 & 369.1 & 368.0 & 366.8 & 368.0 & 366.8 & 368.0 & 361.3 & 368.0 \\
\hline 45 & 376.9 & 376.2 & 373.4 & 371.9 & 367.0 & 369.3 & 365.5 & 364.8 & 357.8 & 361.7 \\
\hline 55 & 378.5 & 384.0 & 374.8 & 372.7 & 365.6 & 363.1 & 352.3 & 352.0 & 336.5 & 342.3 \\
\hline 66 & 375.5 & 382.5 & 370.2 & 371.0 & 357.0 & 355.5 & 338.8 & 338.4 & 324.9 & 323.7 \\
\hline 75 & 381.3 & 386.7 & 378.0 & 371.9 & 351.5 & 351.4 & 324.6 & 329.3 & 314.9 & 310.6 \\
\hline 85 & 363.6 & 368.3 & 358.5 & 361.4 & 342.5 & 341.1 & 321.0 & 319.1 & 312.2 & 300.4 \\
\hline 87 & 376.6 & 376.6 & 370.2 & 368.0 & 348.0 & 345.7 & 322.6 & 320.7 & 304.9 & 300.0 \\
\hline 106 & 380.1 & 388.7 & 373.9 & 370.4 & 338.0 & 336.1 & 308.5 & 301.3 & 285.5 & 281.1 \\
\hline $\bar{R}$ & $0.85^{* * *}$ & & $0.83^{* *}$ & & $0.98^{* * *}$ & & $0.99^{* * * *}$ & & $0.98^{* * * *}$ & \\
\hline RMSE & $4.90^{* * * *}$ & & $2.80^{* * *}$ & & $2.40^{* * * *}$ & & $4.00^{* * *}$ & & $7.5^{* * * *}$ & \\
\hline CV(NRMSE) & $1.30^{* * * *}$ & & $0.80^{* * *}$ & & $0.70^{* * * *}$ & & $1.10^{* * *}$ & & $2.2^{* * * *}$ & \\
\hline NSF & $0.09^{+}$ & & $0.43^{*}$ & & $0.96^{* * *}$ & & $0.97^{* * *}$ & & $0.93^{* * *}$ & \\
\hline D & $0.86^{* *}$ & & $0.85^{* * *}$ & & $0.99^{* * * *}$ & & $0.99^{* * *}$ & & $0.98^{* * *}$ & \\
\hline $\mathbf{R}^{2}$ & $0.72^{* *}$ & & $0.69^{* *}$ & & $0.96^{* * *}$ & & $0.98^{* * *}$ & & $0.96^{* * * *}$ & \\
\hline
\end{tabular}


Table 7. Observed and simulated SWC on Different water level after irrigation 2020 G.C.

\begin{tabular}{|c|c|c|c|c|c|c|c|c|c|c|}
\hline $\mathrm{DaP}$ & $115 \%$ obs & $115 \% \operatorname{sim}$ & $100 \%$ obs & $100 \% \operatorname{sim}$ & $85 \%$ obs & $85 \% \operatorname{sim}$ & $70 \%$ obs & $70 \%$ sim & $55 \%$ obs & $55 \% \operatorname{sim}$ \\
\hline 11 & 384.23 & 378.9 & 380.69 & 378.4 & 373.66 & 378.4 & 368.45 & 378.4 & 371.87 & 378.4 \\
\hline 21 & 405.06 & 386.1 & 402.75 & 386.1 & 383.65 & 386.1 & 382.75 & 386.1 & 380.27 & 386.1 \\
\hline 31 & 418.94 & 421.4 & 415.22 & 416.5 & 408.78 & 411.4 & 396.21 & 406.4 & 393.41 & 402.4 \\
\hline 41 & 424.92 & 424 & 419.09 & 419.7 & 404.50 & 412.5 & 395.40 & 402.4 & 391.76 & 394.1 \\
\hline 52 & 422.05 & 418.5 & 411.45 & 413 & 403.03 & 405.4 & 388.70 & 390.1 & 384.77 & 377.5 \\
\hline 61 & 439.05 & 417.9 & 406.09 & 410.6 & 386.12 & 398.3 & 377.06 & 377.2 & 367.50 & 360.8 \\
\hline 81 & 424.96 & 417.7 & 404.40 & 408.8 & 383.85 & 387.5 & 366.12 & 356.4 & 349.63 & 335.7 \\
\hline 91 & 426.48 & 419.8 & 409.78 & 407.7 & 376.69 & 380.4 & 345.72 & 344.2 & 338.27 & 324.9 \\
\hline 102 & 413.82 & 413.7 & 404.22 & 399.6 & 362.33 & 366.3 & 335.33 & 336.2 & 328.28 & 321.0 \\
\hline 112 & 409.00 & 401.2 & 384.18 & 382.3 & 344.12 & 346.6 & 328.34 & 324.2 & 304.23 & 312.1 \\
\hline $\mathrm{R}$ & $0.88^{* *}$ & & $0.91^{* * *}$ & & $0.99^{* * *}$ & & $0.98^{* * *}$ & & $0.86^{* * *}$ & \\
\hline RMSE t/ha & $10.4^{* * *}$ & & $5.9^{* * *}$ & & $5.9^{* * *}$ & & $6^{* * * *}$ & & $8.9^{* * *}$ & \\
\hline NSE & $0.48^{*}$ & & $0.73^{* *}$ & & $0.89^{* * *}$ & & $0.93^{* * *}$ & & $0.89^{* * *}$ & \\
\hline $\mathrm{D}$ & $0.87^{* *}$ & & $0.94^{* * *}$ & & $0.97^{* * *}$ & & $0.98^{* * * *}$ & & $0.98^{* * * *}$ & \\
\hline
\end{tabular}

observed vs simulated $115 \%$ water level

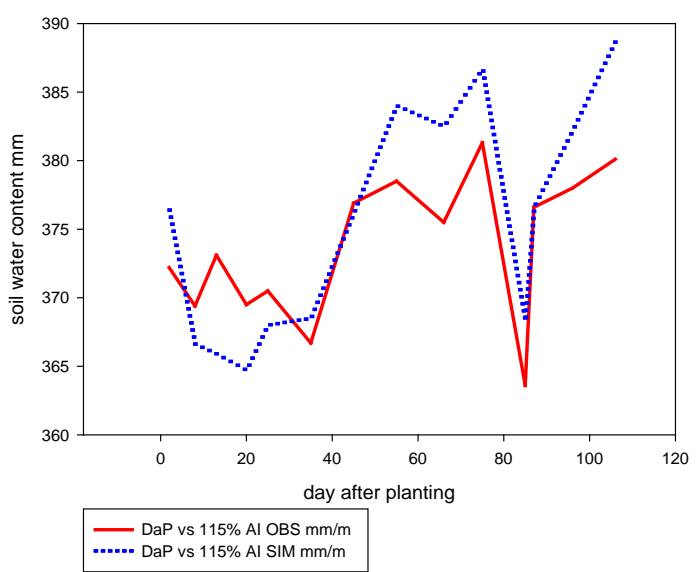

Figure 3. Observed Vs. Simulated at 115\% water level 2019 G.C.

Observed vs. simulated $100 \%$ water level

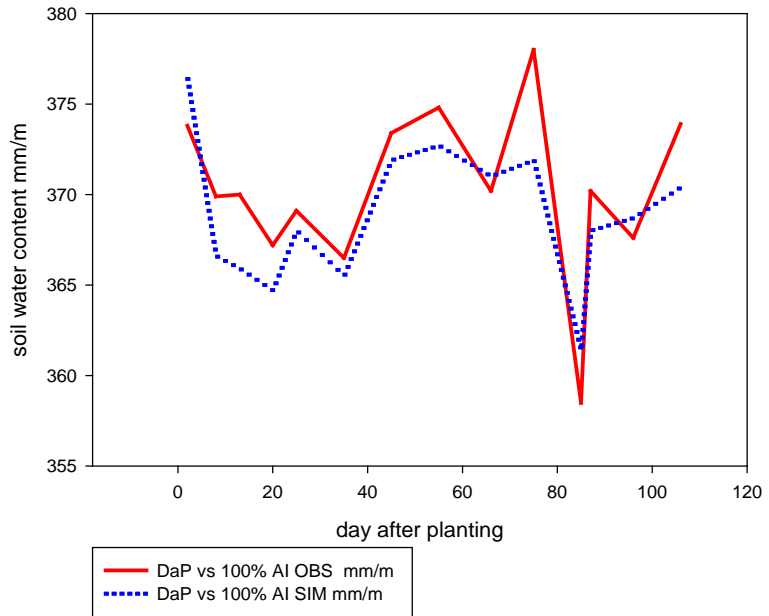

Figure 4. Observed Vs. Simulated at 100\% water level 2019 G.C. 
observed vs, simulated at $85 \%$ water level

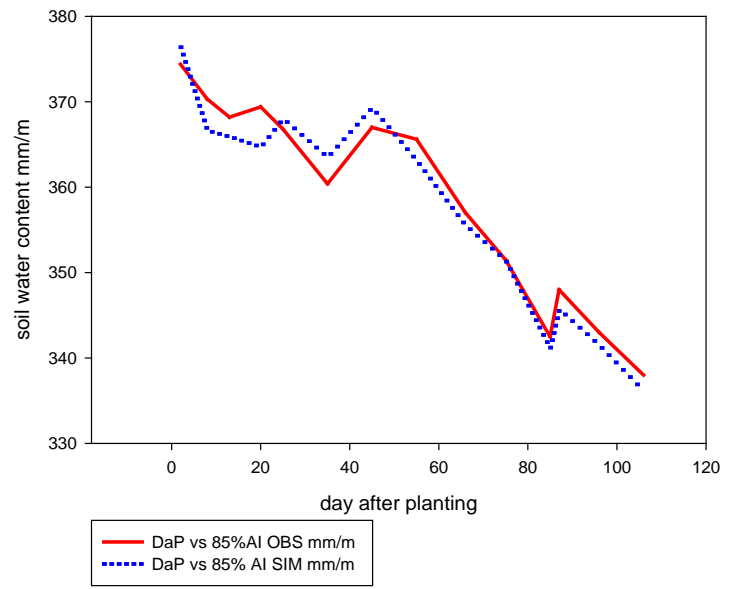

Figure 5. Observed Vs. Simulated at 85 \% water level 2019 G.C.

Observed vs. Simulated at $70 \%$ water level

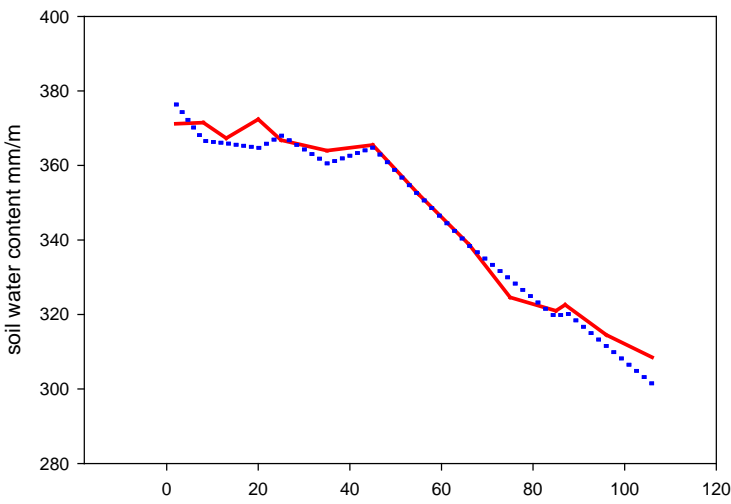

day after planting

DaP vs $70 \%$ Al OBS mm/m DaP vs $70 \%$ Al SIM mm/m

Figure 6. Observed Vs. Simulated at 70 \% water level 2019 G.C.

Observed vs. Simulated at 55\% water level

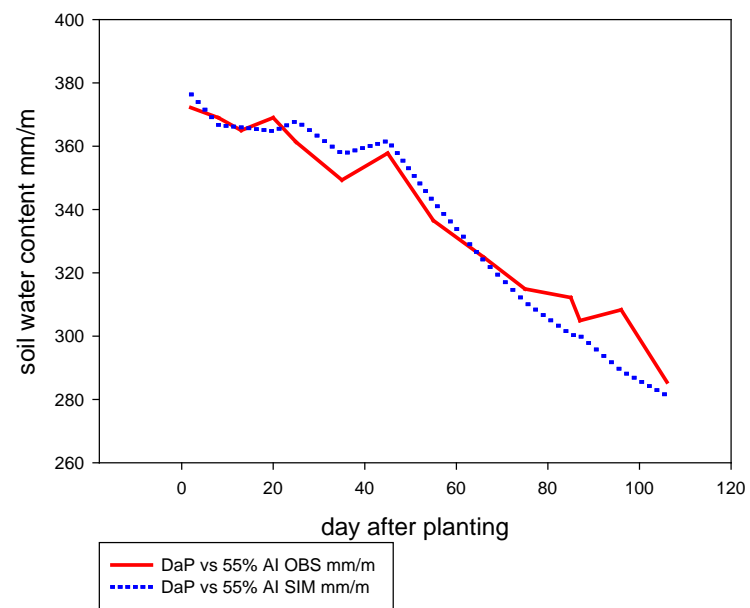

Figure 7. Observed Vs. Simulated at 55 \% water level 2019 G.C. 


\subsection{Effect of water level on, tuber yield and crop water productivity (combined 2019 and 2020)}

As presented in Table 8, the effect of different irrigation water levels on the mean marketable fresh tuber, weight ranges from 36.09 ton/ha to 43.13 ton/ha observed in combined year (2019 and 2020 G.C). There was highly significant difference among treatments at ( $\mathrm{p}<0.05$ ). The water levels $115 \%$ and $100 \%$ water levels had significantly highest value of 43.13 ton/ha and 42.07 ton/ha respectively followed by $85 \%$ and $70 \%$ water level had 38.77 ton/ha and 38.27 ton/ha respectively, but 55\% water level had the least value (36.09 ton/ha) recorded. The results are on the line of FAO, I \& D paper 66 document 40 ton/ha to 50 ton /ha [13]. This result agree with on fresh tuber yield was obtained in Iraq 35.23 ton/ha in furrow irrigation [24]. And also, Birhanu [25] reported 56.85 ton/ha and 39.08 ton/ha fresh potato tuber yield observed in Hirna and Haramaya respectively in 2013, during the main season.

As presented in Table 8, the water productivity on fresh potato tuber ranges $14.12 \mathrm{~kg} / \mathrm{m}^{3}$ to $9.75 \mathrm{~kg} / \mathrm{m}^{3}$ were observed. There was highly significant difference among treatments at $(\mathrm{p}<0.05)$. The water levels 55\% water levels had the highest value $14.12 \mathrm{~kg} / \mathrm{m}^{3}$ followed by $70 \%$ and $85 \%$ water level had $11.50 \mathrm{~kg} / \mathrm{m}^{3}$ and $10.63 \mathrm{~kg} / \mathrm{m}^{3}$ respectively. The least water productivity had 9.75 and $10.47 \mathrm{~kg} / \mathrm{m}^{3}$ was obtained in $115 \%$ and $100 \%$ of water level. This result little higher value than FAO I \& D paper 66 document recorded in the range of $4 \mathrm{~kg} / \mathrm{m} 3$ to $11 \mathrm{~kg} / \mathrm{m}^{3}$ [13]. Another research was found the water productivity on potato crop in Iraq ranges $5.129 \mathrm{~kg} / \mathrm{m}^{3}$ to $7.379 \mathrm{~kg} / \mathrm{m}^{3}$ [24].

Table 8. Combined results in yield and water productivity (2019 and 2020 G.C)

\begin{tabular}{|c|c|c|c|c|c|c|c|c|c|c|}
\hline \multirow{2}{*}{ Parameters } & \multicolumn{5}{|c|}{ Treatments } & \multirow{2}{*}{ Grand Means } & \multirow{2}{*}{ LSD } & \multirow{2}{*}{ CV (\%) } & \multirow{2}{*}{ r2 } & \multirow{2}{*}{ P value $<0.05$} \\
\hline & $115 \%$ & $100 \%$ & $85 \%$ & $70 \%$ & $55 \%$ & & & & & \\
\hline Fresh unmarketable yield ton/ha & 0.88 & 0.76 & 0.95 & 0.94 & 0.87 & 0.880 & ns & 21.3 & 0.70 & $<0.0001$ \\
\hline Fresh marketable yield ton/ha & $43.13^{\mathrm{a}}$ & $42.07^{\mathrm{a}}$ & $38.77^{\mathrm{b}}$ & $38.27^{\mathrm{b}}$ & $36.09^{c}$ & 39.66 & 1.802 & 4.135 & 0.80 & $<0.0001$ \\
\hline Total yield ton/ha & $43.65^{\mathrm{a}}$ & $43.15^{\mathrm{a}}$ & $39.83^{b}$ & $38.92^{\mathrm{b}}$ & $37.67^{c}$ & 40.24 & 1.458 & 3.298 & 0.89 & $<0.0001$ \\
\hline Crop water productivity $\mathrm{kg} / \mathrm{m}^{3}$ & $9.75^{\mathrm{c}}$ & $10.47^{\mathrm{c}}$ & $10.63^{\mathrm{bc}}$ & $11.50^{\mathrm{b}}$ & $14.12^{\mathrm{a}}$ & 11.29 & 0.918 & 7.395 & 0.91 & $<0.0001$ \\
\hline Irrigation mm & $374.9^{\mathrm{a}}$ & $336.8^{\mathrm{b}}$ & $298.7^{\mathrm{c}}$ & $260.7^{\mathrm{d}}$ & $183.7^{\mathrm{e}}$ & 290.9 & 12.3 & 3.834 & 0.989 & $<0.0001$ \\
\hline Irrigation + rainfall mm & $455.9^{\mathrm{a}}$ & $417.8^{\mathrm{b}}$ & $379.7^{c}$ & $341.7^{\mathrm{d}}$ & $264.7^{\mathrm{e}}$ & 371.9 & 12.3 & 2.999 & 0.986 & $<0.0001$ \\
\hline
\end{tabular}

\subsection{Yield and water productivity advantages on potato crop}

As presented in Figure 8, the 115\% of water level had $8.33 \%$ of extra water used over $100 \%$ of water level, while the $85 \%, 70 \%$ and $55 \%$ of water level had $8.33 \%, 16.65 \%$, and $24.98 \%$ of water save respectively as compared to $100 \%$. The $55 \%$ of water level had extra $25 \%$ of hectare of land opportunity observed while 55\% water level, punished by $18 \%$ of yield as compared to a $100 \%$ of water level. However, the $115 \%$ water level had $8.3 \%$ of hectare of land punished as compared to $100 \%$ water level and $3 \%$ of yield advantages was recorded.

yield vs. water productivity advantage over $100 \%$

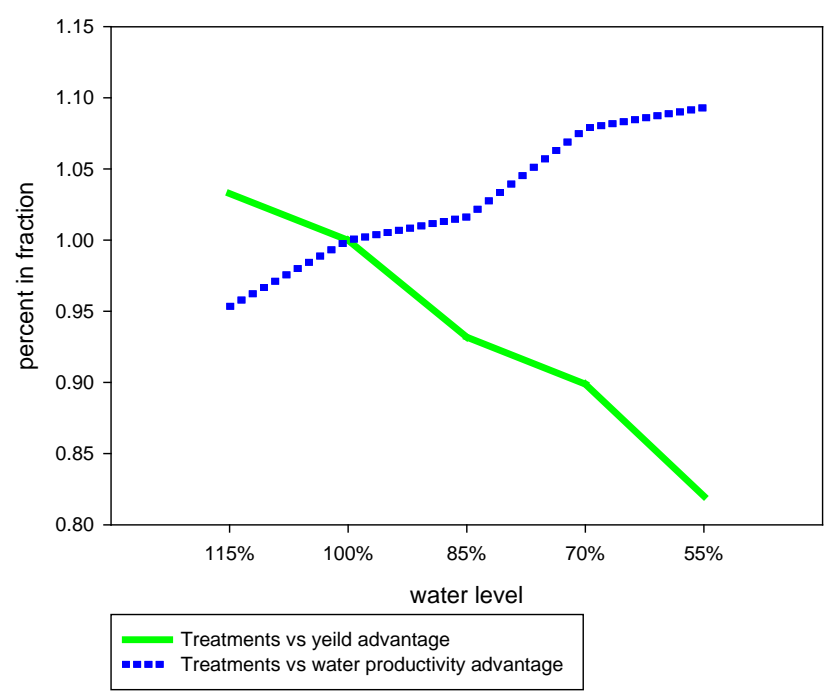

Figure 8. Yield vs water productivity opportunities. 


\subsection{Evapotranspiration water productivity}

As presented in Figure 9, the evapotranspiration water productivity obtained from actual field experiment at $100 \%$ water level was found to be $11.59 \mathrm{~kg} / \mathrm{m}^{3}$ and $12.86 \mathrm{~kg} / \mathrm{m}^{3}$ in the year 2019 G.C and 2020G.C respectively. The results show that the AquaCrop model a little bit over estimated that was $13.36 \mathrm{~kg} / \mathrm{m}^{3}$ as compared to the actual experimental yield.

\section{long term simulated vs two year observed on water productivity $\mathrm{kg} / \mathrm{m} 3$}

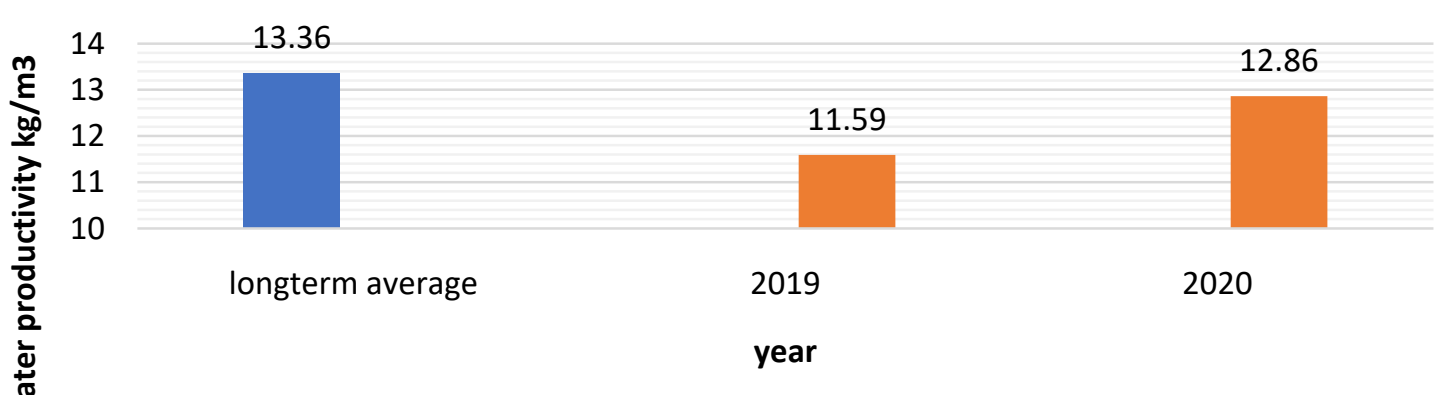

long term average $\mathrm{kg} / \mathrm{m3} \quad$ at field exeriment WP KG/M3

Figure 9. Water productivity on fresh potato tuber.

\subsection{Partial Budget Analyses}

As presented in Table 9, high marginal rates of returns (MRR, 26.1\% and 22.5\%) and in Table 10 in combined year (MRR, 16.17\% and 25\%) were also observed under $70 \%$ and $100 \%$ water levels, respectively. Meanwhile, the marginal rate of return under both the $115 \%$ and $85 \%$ water levels was found to be 10.3 in combined year. Thus, $70 \%$ and $100 \%$ water levels resulted in better results and in line with a study conducted in Spain that higher yields were obtained under $100 \%$ and $80 \%$ water level [23].

Table 9. Total variable cost, net benefit and marginal rate of return (MRR) 2019

\begin{tabular}{|c|c|c|c|c|c|c|c|c|c|}
\hline Treatment & AY kg/ha & ADY kg/ha & FP/KG (ETB) & GFB/KG (ETB) & TVC (ETB/ha) & NB (ETB/ha) & MC & MB & MRR \\
\hline $55 \%$ & 35,850 & 32,265 & 20.00 & 645,300 & $8,374.6$ & $6,369,254$ & & & \\
\hline $70 \%$ & 39,290 & 35,361 & 20.00 & 707,220 & $10,658.5$ & 696,562 & 2,284 & 59,636 & 26.1 \\
\hline $85 \%$ & 40,730 & 36,657 & 20.00 & 733,140 & $12,942.5$ & 720,198 & 2,284 & 23,636 & 10.3 \\
\hline $100 \%$ & 43,710 & 39,339 & 20.00 & 786,780 & $15,226.5$ & 771,554 & 2,284 & 51,356 & 22.5 \\
\hline $115 \%$ & 45,140 & 40,626 & 20.00 & 812,520 & $17,510.4$ & 795,010 & 2,284 & 23,456 & 10.3 \\
\hline
\end{tabular}

Notes. AY is average yield $\mathrm{kg} / \mathrm{ha}$, ADY is (-10\%) adjusted yield $\mathrm{kg} / \mathrm{ha}$, FP is field price per $\mathrm{kg}$, GFB is gross filed benefit $\mathrm{kg} / \mathrm{ha}$, TVC is total variable cost (Birr/ha), NB is net benefit (Birr/ha) MC is marginal cost, MB is marginal benefit and MRR is marginal rate of return.

Table 10. Total variable cost, net benefit and marginal rate of return (MRR) combined year

\begin{tabular}{cccccccccc}
\hline Treatment & AY kg/ha & ADY kg/ha & FP/KG (ETB) & GFB/KG (ETB) & TVC (ETB/ha) & NB (ETB/ha) & MC & MB & MRR \\
\hline $\mathbf{5 5 \%}$ & $36,087.9$ & $32,479.11$ & 20 & $649,582.2$ & $8,374.6$ & $641,207.6$ & & & \\
$\mathbf{7 0 \%}$ & $38,266.6$ & $34,439.94$ & 20 & $688,798.8$ & $10,658.5$ & $678,140.3$ & $2,283.9$ & $36,932.7$ & 16.17089 \\
$\mathbf{8 5 \%}$ & $38,768.6$ & $34,891.74$ & 20 & $697,834.8$ & $12,942.5$ & $684,892.3$ & 2,284 & 6,752 & 2.956217 \\
$\mathbf{1 0 0 \%}$ & $42,068.1$ & $37,861.29$ & 20 & $757,225.8$ & $15,226.5$ & $741,999.3$ & 2,284 & 57,107 & 25.00306 \\
$\mathbf{1 1 5 \%}$ & $43,128.2$ & $38,815.38$ & 20 & $776,307.6$ & $17,510.4$ & $758,797.2$ & $2,283.9$ & $16,797.9$ & 7.354919 \\
\hline
\end{tabular}




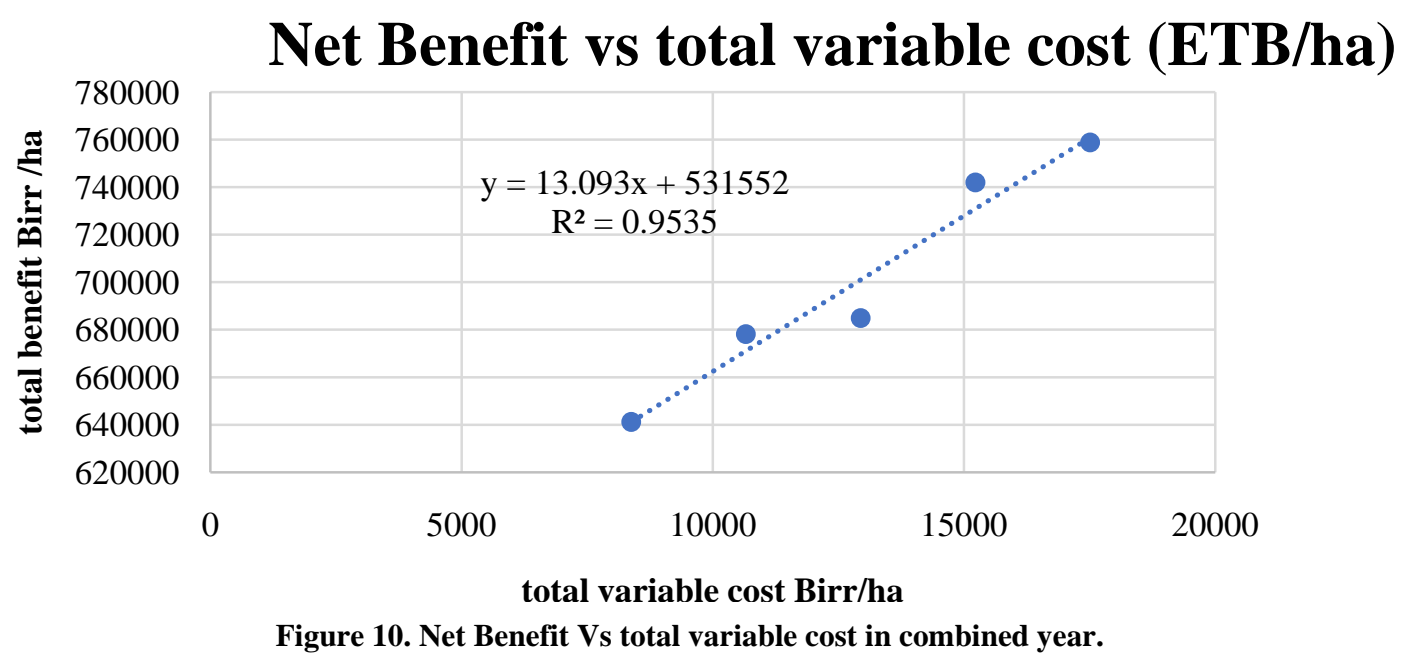

As presented in Figure 10 in $70 \%$ and $100 \%$ water level showed that above the fitted line while 50\%, 85\% and $115 \%$ had on and below the line This $\mathrm{R}^{2}$ value $(0.9535)$ was indicated that $95.35 \%$ of variation comes from treatment variation. The highest marginal rate of return (25.00\% and $16.17 \%$ ) was also observed for $70 \%$ and $100 \%$ water level respectively. While, the water level $115 \%$ and $85 \%$ was $7.35 \%$ and $2.95 \%$ respectively, while the water level $55 \%$ as control (least cost). Results in the line with as reported in Spain, the higher yield in 100\% and 80\% [23].

\section{Conclusion and recommendations}

The following points are given as concluding remarks based on the results of this study.

$\checkmark \quad$ The AquaCrop model simulated results showed that for $100 \%$ was $3,772.0 \mathrm{~m}^{3} /$ ha used in growing season. For the rest of other water levels used as corresponding of their percentage of the $100 \%$ water level $\left(4,086.1 \mathrm{~m}^{3} / \mathrm{ha}\right.$, $3,457.9 \mathrm{~m}^{3} / \mathrm{ha}, 3,143.8 \mathrm{~m}^{3} / \mathrm{ha}$ and $2,829.8 \mathrm{~m}^{3} /$ ha of water used for $115 \%, 85 \%, 70 \%$ and $55 \%$ of water level respectively.

$\checkmark \quad$ Based on the results of the model performance indictors used in this study, the AquaCrop model was found to well simulate all considered crop parameters. The AquaCrop model performance in the canopy cover, dry aboveground and tuber biomass and soil water content of the potato crop. The statistical indicators; Nash-Sutcliffe efficiency (NSE), Normalized Root mean square error (NRMSE) index of agreement (d) and Coefficient of determination ( ${ }^{2}$ ) showed very well to excellent efficiency, there value is in ranges on aboveground and tuber biomass ranges 0.78 to 0.99, 14.1 to $35.5,0.96$ to 0.99 and 0.96 to 0.98 was observed respectively. However, the result of soil water content before irrigation was found to be poor efficiency ranges -0.96 to $0.00,10.2$ to $10.7,0.5$ to 0.780 .081 to 0.45 respectively in the above order.

$\checkmark \quad$ The statistical analysis had highly significantly affected on growth parameters and yield of potato crop on different water level. The fresh potato yield ranges from 36.09 ton/ha to 43.13 ton/ha was obtained in 55\% and $115 \%$ water levels respectively. The water levels $115 \%$ and $100 \%$ water levels had significantly highest value of 43.13 ton/ha and 42.07 ton/ha respectively followed by $85 \%$ and $70 \%$ water level had 38.77 ton/ha and 38.27 ton/ha respectively, but 55\% water level had the least value (36.09 ton/ha) recorded. The water productivity ranges from 11.59 $\mathrm{kg} / \mathrm{m}^{3}$ to $12.67 \mathrm{~kg} / \mathrm{m}^{3}$ was obtained in $55 \%$ and $115 \%$ water level respectively. The best combination among the treatment was found to be on the water level of $100 \%$ for no water scarce area and $70 \%$ under water scarce area.

$\checkmark \quad$ The results of partial budget analyses showed that $70 \%$ and $100 \%$ water levels best fitted the net benefit with the total variable cost being above the trend line. The highest marginal rates of return $(26.1 \%$ and $22.5 \%)$ were obtained under for $70 \%$ and $100 \%$ water levels, respectively. Therefore, I recommended in the study area and similar area with two scenarios. The first one is under "water scarce" condition, farmers should apply $70 \%$ of the irrigation water requirement with 10-days irrigation interval. On the other hand, under "no water scarce" condition", farmers should apply $100 \%$ irrigation water requirement with 10 -days irrigation interval.

\section{References}

[1] Hagos, F., Makombe, G., Namara, R. E., and Awulachew, S. B. (2010). Importance of Irrigated Agriculture to the Ethiopian Economy: Capturing the direct net benefits of irrigation. Ethiopian Journal of Development Research, 32(1). 
[2] Bewket Woldeamlak. (2009). Rainfall Variability and Crop Production in Ethiopia: Case study in the Amhara region. In proceedings of the $16^{\text {th }}$ international conference of Ethiopian Studies (Vol. 3. Pp. 823-836). Trondheim Norway: Norwegian University of Science and Technology.

[3] Tadesse Adisie. (2016). Household food insecurity and copying mechanisms in menze Gera district of Amhara regional state, central Ethiopia. An M.Sc Thesis presented to the school of graduate studies of Haramaya University.

[4] GIDA and JICA. (2004). Strategies for Effective Utilization of Existing Irrigation Projects. Pp. 2.

[5] Makombe, G., Kelemework, D., and Aredo, D. (2007). A comparative analysis of rainfed and irrigated agricultural production in Ethiopia. Irrig Drainage Syst., 21: 35-44.

[6] World Bank. (2006). The World Bank Annual Report 2006. Washington, DC. (C) World Bank. https://openknowledge.worldbank.org/handle/10986/7526 License: CC BY 3.0 IGO.

[7] Food and Agriculture Organization (FAO). (1990). Crop water information: potato. Accessed at cropinfo_potato.html.

[8] Dessalegn, S. (2015). Sorghum Response to Soil Moisture Stress Condtion at Different Crop Growth Stages in Central Rift Valley, Ethiopia, Doctoral dissertation, Haramaya University.

[9] Bessember, J., Leffelaar, P., and Dhindwal, A. (2005). Which crop and which drop, and the scope for improvement of water productivity: Agricultural water management, v. 73, no. 2, pp. 113-130.

[10] Stockle, C. O., Donatelli, M., and Nelson, R. (2003). CropSyst, a cropping systems simulation model. European journal of agronomy, 18(3-4), 289-307.

[11] Jones, C. A. (1986). CERES-Maize; a simulation model of maize growth and development (No. 04; SB91. M2, J6.).

[12] Van Ittersum, M. K., Cassman, K. G., Grassini, P., Wolf, J., Tittonell, P., and Hochman, Z. (2013). Yield gap analysis with local to global relevance: a review. Field Crops Res., 143, 4-17.

[13] Food and Agriculture Organization (FAO). (2012). Production Year Book, 2011. Accessed http://faostat.fao.org/.

[14] Steduto, P., Hsiao, T. C., Fereres, E., and Raes, D. (2012). Crop yield response to water (Vol. 1028). Rome: Food and Agriculture Organization of the United Nations.

[15] Steduto, P., Hsiao, T. C., Raes, D., and Fereres, E. (2009). AquaCrop-The FAO crop model to simulate yield response to water: I. Concepts and underlying principles. Agronomy Journal, 101(3), 426-437.

[16] Raes, D. P., Steduto, T.C., Hsiao, T. C., and Fereres, E. (2009). AquaCrop-The FAO Crop Model to simulate predicting yield response to water. II. Main algorithms and software description. Agronom. Journal, 101(3): 438-447.

[17] Food and Agriculture Organization (FAO). (2005). FAOSTAT Agricultural Data. Agricultural production, crops, primary. Available at http://faostat.fao.org,/, faostat/collections? Subset = agriculture. Verified on 17 March 2005. United Nations Food and Agriculture Organization.

[18] Hirpa, A., Meumissen, M. P. M., Tesfaye, A., Wiranda, P. M., et al. (2010). 'Analysis of Seed Potato Systems in Ethiopia'. American Journal of Potato Research, 87(6), pp. 537-552. doi: 10.1007/s12230-010-9164-1.

[19] Yilma, S. (1991). The potential of true potato seed in potato production in Ethiopia. Acta Hurticultrae, 270: 389-394.

[20] Doorenbos, J. and Pruitt, W. J. (1977). Guidelines for predicting crop water requirements. Irrigation and Drainage Paper No. 24, FAO, Rome.

[21] Russel, F. D. (1990). M. Stat crop directory. Michigan State Univerity, East Lansing. MI.

[22] Yibrah, G., Araya, B., and Amsalu, N. (2015). Performance of AquaCrop Model in Predicting Tuber Yield of Potato (Solanum tuberosum L.) under Various Water Availability Conditions in Mekelle Area, Northern Ethiopia Journal of Natural Sciences Research www.iiste.org ISSN 2224-3186 (Paper) ISSN 2225-0921 (Online) Vol.5, No.5, 2015.

[23] Montoya, F., et al. (2016). 'Evaluation of Aquacrop model for a potato crop under different irrigation conditions', Agricultural Water Management. Elsevier B.V., 164, pp. 267-280. doi: 10.1016/j.agwat.2015.10.019.

[24] Ati, A. S., Iyada, A. D., and Najim, S. M. (2012). 'Water use efficiency of potato (Solanum tuberosum L.) under different irrigation methods and potassium fertilizer rates’, Annals of Agricultural Sciences. Faculty of Agriculture, Ain Shams University, 57(2), pp. 99-103. doi: 10.1016/j.aoas.2012.08.002.

[25] Birhanu, T. (2014). Growth, yield, and quality of Potato (Solanum tuberosum L.) cultivars as influenced by plant spacing at Haramaya and Hirna, Eastern Ethiopia. 


\section{Appendix}

Appendix Table 1. Non-conservative parameters used for AquaCrop Potato Model

\begin{tabular}{cc}
\hline Non-conservative (crop specific) parameters & Values \\
\hline Plant density (plants ha-1) & $44,444.44$ \\
Initial canopy cover CCo (\%) & 0.67 \\
Maximum canopy cover CCx (\%) & 88 \\
Time to maximum canopy cover (d) & 60 \\
Time to flowering (d) & 51 \\
Length of the flowering stage (d) & 27 \\
Time to senescence (d) & 95 \\
Time to maturity (d) & 115 \\
Maximum rooting depth (m) & 0.70 \\
Minimum effective rooting depth (m) & 0.50 \\
Reference harvest index HIo (\%) & 75
\end{tabular}

Appendix Table 2. Conservative parameters used for AquaCrop Potato Model

\begin{tabular}{cc}
\hline Conservative parameters & Values \\
Base temperature $\left({ }^{\circ} \mathrm{C}\right)$ & 2 \\
Upper temperature $\left({ }^{\circ} \mathrm{C}\right)$ & 26 \\
Cover per seedling (cm 2 plant-1) & 0.4 \\
Canopy growth coefficient CGC (\% d-1) & 0.14 \\
Canopy decline coefficient CDC (\% d-1) & 0.08 \\
Soil water depletion factor for canopy expansion, upper limit & 0.25 \\
Soil water depletion factor for canopy expansion, lower limit & 0.55 \\
Shape factor for Water stress coefficient for canopy expansion & 0 \\
Soil water depletion factor for stomata closure & 0 \\
Shape factor for Water stress coefficient for stomata closure & 0 \\
Soil water depletion factor for early canopy senescence & 0 \\
Shape factor for Water stress coefficient for canopy senescence & 18 \\
Normalized water productivity WP* $\left(\mathrm{g}\right.$ m ${ }^{-2}$ ) & 18 \\
Normalized water productivity during yield formation WP* $\left(\mathrm{g} \mathrm{m}{ }^{-2}\right.$ ) & 0 \\
\hline
\end{tabular}

Appendix Table 3. Results yield and yield parameters and water productivity 2019G.C

\begin{tabular}{|c|c|c|c|c|c|c|c|c|c|c|}
\hline \multirow{2}{*}{ Parameters } & \multicolumn{5}{|c|}{ Treatments } & \multirow{2}{*}{$\begin{array}{l}\text { Grand } \\
\text { Means }\end{array}$} & \multirow{2}{*}{ LSD } & \multirow{2}{*}{ CV (\%) } & \multirow{2}{*}{ r2 } & \multirow{2}{*}{$\begin{array}{l}\mathrm{P} \text { value } \\
<0.05\end{array}$} \\
\hline & $115 \%$ & $100 \%$ & $85 \%$ & $70 \%$ & $55 \%$ & & & & & \\
\hline $\begin{array}{l}\text { Fresh unmarketable yield } \\
\text { ton/ha }\end{array}$ & $0.77^{\mathrm{a}}$ & $0.69^{\mathrm{ab}}$ & $0.67^{\mathrm{ab}}$ & $0.66^{\mathrm{b}}$ & $0.61^{\mathrm{b}}$ & 0.681 & 0.102 & 9.704 & 0.73 & 0.0096 \\
\hline $\begin{array}{l}\text { Fresh marketable yield } \\
\text { ton/ha }\end{array}$ & $44.37^{\mathrm{a}}$ & $43.02^{\mathrm{a}}$ & $40.06^{\mathrm{b}}$ & $38.63^{\mathrm{b}}$ & $35.25^{c}$ & 40.27 & 1.742 & 2.808 & 0.94 & $<0.0001$ \\
\hline Total yield ton/ha & $45.14^{\mathrm{a}}$ & $43.71^{\mathrm{a}}$ & $40.73^{\mathrm{b}}$ & $39.29^{b}$ & $35.85^{c}$ & 40.95 & 1.758 & 2.787 & 0.94 & $<0.0001$ \\
\hline $\begin{array}{l}\text { Crop water productivity } \\
\qquad \mathrm{kg} / \mathrm{m}^{3}\end{array}$ & $11.05^{\mathrm{c}}$ & $11.59^{b}$ & $11.78^{\mathrm{b}}$ & $12.5^{\mathrm{a}}$ & $12.67^{\mathrm{a}}$ & 11.92 & 0.509 & 2.599 & 0.98 & $<0.0001$ \\
\hline Irrigation mm & $311.8^{\mathrm{a}}$ & $280.4^{\mathrm{b}}$ & $249^{c}$ & $217.6^{\mathrm{d}}$ & $186.1^{\mathrm{e}}$ & 235.4 & 0 & 0 & 1 & $<0.0001$ \\
\hline Irrigation + rainfall mm & $408.6^{\mathrm{a}}$ & $377.2^{\mathrm{b}}$ & $345.8^{\mathrm{c}}$ & $314.4^{\mathrm{d}}$ & $282.9^{e}$ & 332.2 & 0 & 0 & 1 & $<0.0001$ \\
\hline
\end{tabular}

